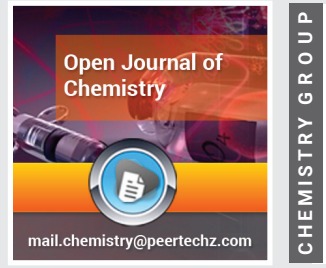

\section{Liquid Chromatography-} Mass Spectrometry studies

\section{on molecular structure of melatonin after Co-60 gamma irradiation}

\author{
Ahmad-Reza Safdari ${ }^{1}$ and Mehran Babri2* \\ 'Department of Physics, Faculty of Basic Sciences, Imam Hussein comprehensive University, Tehran, \\ Iran \\ ${ }^{2}$ Defense Chemical Research Lab (DCRL), P.O.BOX: 31585-1461, Karaj, Iran
}

Received: 03 December, 2019

Accepted: 06 February, 2020

Published: 07 February, 2020

*Corresponding author: Mehran Babri, Defense Chemical Research Lab (DCRL), P.O. Box 31585-1461, Karaj, Iran, E-mail: babri@dcrl.ir

Keywords: Gamma rays; Chemical structure; Melatonin; Radioprotective agent; LC-MS

https://www.peertechz.com

Check for updates

\begin{abstract}
In this work, effects of gamma rays on melatonin as a natural radioprotective agent, have been studied. Selected samples in the form of a) powder and b) solution, were prepared and irradiated by the use of gammacell radiation system under gamma-ray of Co- 60 source, at doses from 20 to $2150 \mathrm{~Gy}$. The content of irradiated sample vials compared with of the control samples using LC-MS. This revealed many changes, although only in solution samples. Observed changes in the structure of melatonin in aqueous solutions, could be related to the production of free hydrogen and hydroxyl radicals; since both reduction and oxidation products were detected. Any increase in gamma ray doses would cause, proportional decrease in melatonin concentrations as well as increase in reaction products'concentrations. The lack or low impact of gamma rays on solids are related to the low collision crosssection of melatonin for photons, as compared with the water molecules in aqueous solutions.
\end{abstract}

\section{Abbreviations}

MLT: Melatonin; LC-MS: Liquid Chromatography-Mass Spectrometry; ESI: Electrospray Ionization System; HPLC: High Performance Liquid Chromatography; amu: atomic mass unit

\section{Introduction}

Radiation protection chemicals are compounds which are used to prevent, protect and treat living organisms against harmful damages of ionizing radiations. So, it is expected when they are applied before, during or after a human or animal exposure, the detrimental effects of ionizing radiation would be considerably reduced [1-4].

At some levels, organism's immune system naturally is able to protect body against damages caused by radiations, and can detoxify and eliminate harmful effects of ionizing radiation.
However, for high radiation doses, immune system cannot provide an acceptable level of protection [3].

Effectiveness of some compounds in protection against ionizing radiation was first discovered by Dale, Gray and Meredith in 1942, and their findings were published in 1948 [1]. In the early 1950s, the United States Atomic Energy Commission launched a program to make radioprotectors [1]. Despite the effectiveness of some chemicals in relatively short time, these compounds were almost toxic and caused nausea and vomiting at the protection doses [1]. Several years after acquiring more knowledge about the role of free radicals produced in various tissues of living organisms due to ionizing radiation and their effects on vital molecules, including DNA, a sort of mechanisms for radioprotection were explained [1]. Walter Reed Army Institute of Research started to perform a comprehensive program in order to synthesize some radioprotective agents during 1957-1986 [1]. An agent which 
was introduced through this program was a phosphorothioate compound known as amifostine, which is still one of the most effective radiation protection agent [1].

Natural radioprotective agents are selected by looking to their antioxidant and immune system stimulation activities [3]. The highest impact of these compounds should be the protection against biological damage and side effects of radiation toxicity $[3,4]$. Natural radioprotective agents have less protection potency than specially designed chemicals for such applications; however, their effects usually lasted more than synthesized chemicals. Also, their lower toxicity and side effects as well as the possibility of oral consumption, made them more suitable for radioprotection $[2,3]$.

Today, the use of natural and specially designed radioprotective agents is necessary in radiotherapy and treatment of cancers, in order to protect healthy cells of patient's body, as well as radiotherapists who may exposed during the operation [3].

As a natural radioprotective agent, MLT (N-acetyl-5methoxytryptamine) is one of the hormones of pituitary gland which is synthesized in the pineal gland in human brain and quickly enters the bloodstream and through blood to other body fluids such as bile, cerebrospinal fluid, saliva, the follicular fluid of the ovary and semen [5]. Unlike amifostine, MLT could easily pass through the blood brain barrier [6]. This chemical was discovered by Lerner, et al., in 1958 [5] and its radioprotective effectiveness was demonstrated in 1993 [7]. After reaction with hydroxyl and peroxyl radicals, MLT is oxidized to melatonyl, and through molecular rearrangements, cyclic 3hydroxymelatonin is produced [5]. Also, MLT is able to increase the activity of certain antioxidant enzymes such as superoxide dismutase, glutathione peroxidase, glutathione reductase and catalase at the molecular level, and suppresses the activity of the pro-oxidative enzymes [5]. In addition, Cui, et al., suggested other interesting properties for this chemical, specifically, its anti-inflammatory, and anti-apoptotic as well as its anti-proliferative effects and apoptosis induction in cancer cells [8]. Jang, et al., introduced MLT as a radiation sensitizer in cancer cells to induce an increase in apoptosis, and as a protector of normal cells by regulation of gene expression and, consequently, the reduction of apoptotic activity [9]. Lissoni, et al., found that MLT is a natural angiogenesis inhibitor in cancer cells that controls the tumor tissues as radiation dose during radiotherapy is increased [10].

The present study aims to investigate effects of Co-60 gamma radiation on chemical structure of MLT in solid form and aqueous solutions. Based on our literature survey, no scientific reports have been presented about the effects of gamma radiation on chemical structure of MLT. Therefore, results of this study may help us in the use/non-use of drugs containing MLT, in a) contaminated areas due to the actuation by an active agent; and in b) radioactive disasters caused by losing, theft or missing the active sources, and spread of radioactive contamination, for instance into medical centers.

\section{Materials and methods}

\section{Chemical and reagents}

Pure MLT was procured from Sigma-Aldrich. Ethanol, HPLC grade, were from Merck.

Two sample groups were prepared: a) powder samples; $4 \mathrm{ml}$ vials each containing $40 \mathrm{mg}$ MLT and $\mathrm{b}$ ) aqueous samples; $4 \mathrm{ml}$ vials containing $1.5 \mathrm{ml} 100 \mathrm{mg} / \mathrm{L}$ MLT solution. One sample in each group was taken as control sample.

\section{Preparation of test samples}

To prepare a 100mg/L solution of MLT, 10mg of MLT powder was weighed in a small beaker and $500 \mu \mathrm{L}$ of absolute ethanol was added to it. Then, the solution was poured into a $10 \mathrm{ml}$ volumetric flask. The weighing container was washed with a small amount of absolute ethanol, which was then added to the volumetric flask. The volume of the solution in the volumetric flask was increased to $10 \mathrm{ml}$ with addition of absolute ethanol. This solution was considered as a stock solution with a concentration of $1000 \mathrm{mg} / \mathrm{L}$. Then, with dilution using distilled water $10 \mathrm{ml} 100 \mathrm{mg} / \mathrm{L}$ solution of MLT was prepared and poured into six $4 \mathrm{ml}$ vials, each containing $1.5 \mathrm{ml}$ sample. The aliquot samples were stored at $-20^{\circ} \mathrm{C}$.

\section{Irradiation of samples}

Irradiation of the samples was carried out by Gammacell (GC-220) irradiation system from Nordion, Ottawa, Canada with a dose rate of $1.61 \mathrm{~Gy} / \mathrm{sec}$ and activity of $6744 \mathrm{Ci}$. Five powder and five solution samples were irradiated with gamma rays at doses of $20,50,120,500$ and $2150 \mathrm{~Gy}$ in $9 \mathrm{sec}, 28 \mathrm{sec}$, 1min: 11sec, 5min: $8 \mathrm{sec}$ and $22 \mathrm{~min}: 12 \mathrm{sec}$, respectively. The irradiated samples were kept at $-20^{\circ} \mathrm{C}$ away from the light.

\section{Instrumentation}

To investigate possible changes in molecular structure of MLT in irradiated solid and solution samples, LC-MS was used. This system consists of an Agilent 1200 series LC which has equipped with a zorbax eclips XDB-C18 solvent saver plus HPLC column, $150 \mathrm{~mm}$ length, $3 \mathrm{~mm}$ i.d. and $3.5 \mu \mathrm{m}$ particle size, at $25^{\circ} \mathrm{C}$. The eluent composition under elution programming was prepared using A) $15 \mathrm{mM}$ formic acid solution in water and B) $15 \mathrm{mM}$ formic acid in acetonitrile. The optimized elution program was $0-3 \mathrm{~min}, 5 \% \mathrm{~B}$, followed by gradually increment of B percent in eluent, from 5 to $100 \%$ until $15 \mathrm{~min}$. The flow rate of elution solvent, and sample injection volume were $0.3 \mathrm{ml} / \mathrm{min}$ and $1 \mu \mathrm{l}$, respectively. Chromatographic peak purity assessment was done using most intense ions in MS spectra under each peak.

The MS data were collected using Agilent 6410 Triple Quad MS with an electrospray ionization system. ESI voltage was at $4 \mathrm{kV}$, and MS scan range was between 70 to $700 \mathrm{~m} / z$. Each scan lasted for 500msec.

In these experiments, soluble samples were examined directly, but solid samples were dissolved in water and examined at a concentration of $278 \mathrm{mg} / \mathrm{L}$. 


\section{Results and discussion}

\section{LC-MS analysis of sample solutions}

The MLT retention time as the major compound, under chromatographic condition is $13.3 \mathrm{~min}$ (Figure 1). Based on structural information, the MS spectrum of MLT (Figure 2) was interpreted and identified ions were assigned.

Clearly, the content of an irradiated sample solution with gamma rays at dose of $2150 \mathrm{~Gy}$, in comparison with the control sample (Figure 1), was changed and some new peaks which are related to the formation of irradiation products are seen (Figure 3). Major irradiation products I, II and III are eluted from chromatographic column, at $11.6,12.0$ and $12.8 \mathrm{~min}$, respectively. The focus of this report is on the identification of these compounds. Summary of analytical results obtained through the analysis of the other sample solutions are provided in Table 1. It is obvious that under even 2150Gy gamma-ray irradiation, about $95 \%$ of MLT molecules, in aqueous solution, are intact.

\section{LC-MS analysis of solid samples}

The chromatograms and ESI mass spectra of irradiated and control solid samples showed no any difference and are not presented in this paper.

\section{Solution samples analyses}

Considering the contents of Table 1 , it can be concluded that by increasing the radiation dose, MLT concentration is relatively reduced and new compounds are formed which their concentration are gradually increased. A close look at chromatographic data (Table 1), shows that under exposure to gamma rays, a part of MLT is degraded into other compounds, mostly I, II and III. Due to the ESI-MS detection limit at the mentioned condition, some irradiation products can be seen in the solutions which were exposed at doses greater than 50Gy.

In order to identify product compounds using the ESI-MS spectra, without access to any MS library, not only probable ions' fragmentation and formation processes, but also starting compounds and possible reasonable reactions should be taken into account.

The first possible reaction pathway is the radical degradation of water by gamma rays and creation of hydroxyl radical $(\cdot \mathrm{OH})$ and hydrogen atom. ESI-MS spectrum of the MLT irradiation product, I, which left the LC column at $11.6 \mathrm{~min}$ (Figure 4 ),

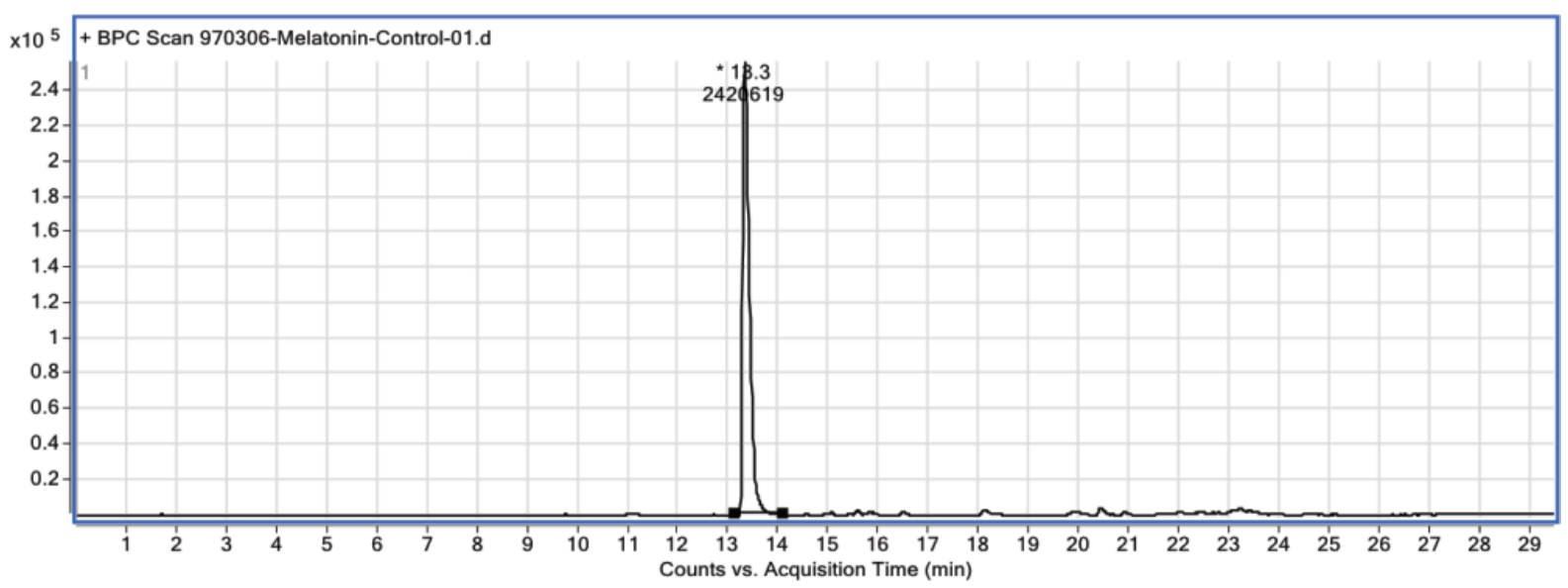

Figure 1: Chromatogram of the MLT control sample solution.

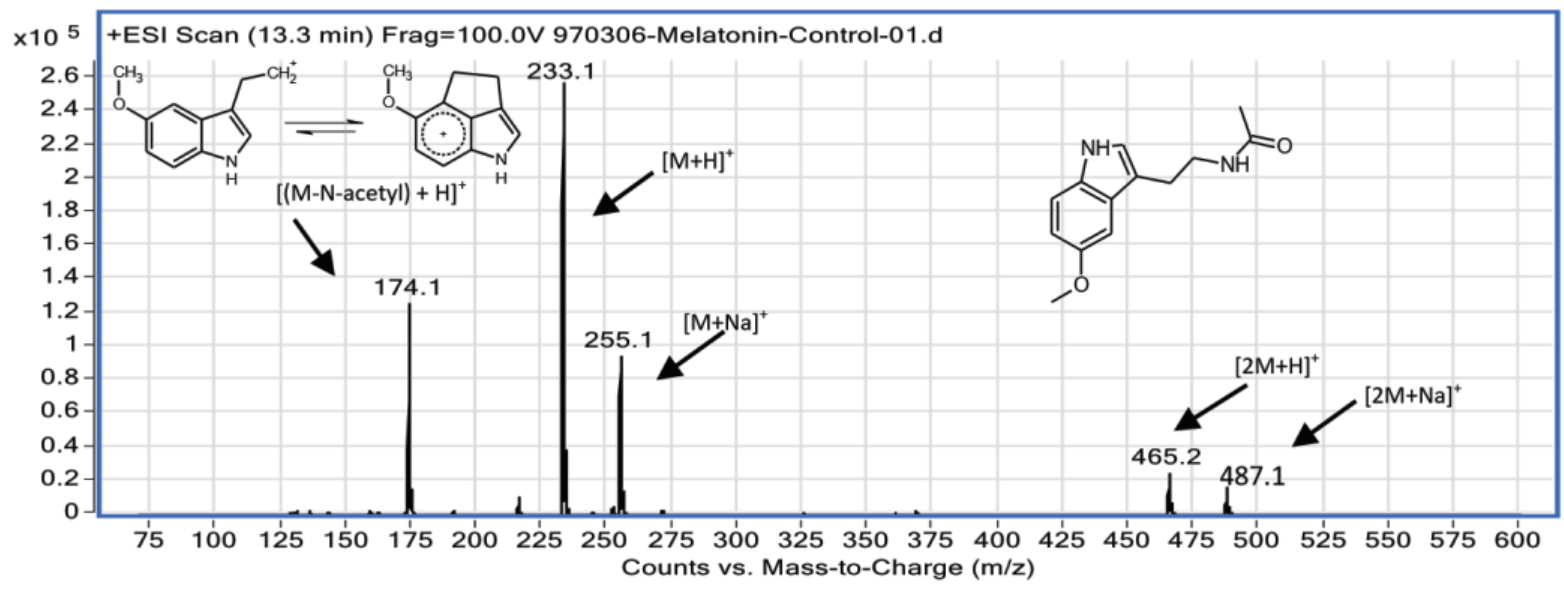




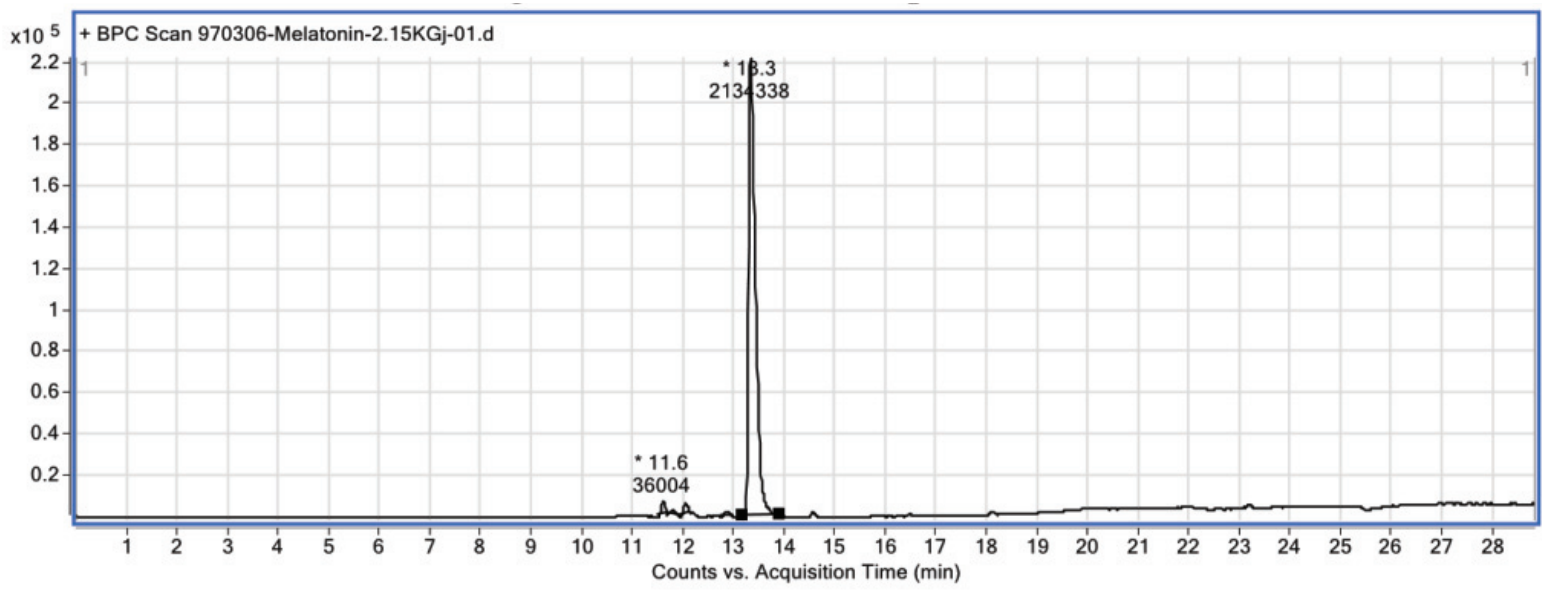

Figure 3: Chromatogram of the MLT sample solution, irradiated with gamma-ray at dose of 2150Gy.

Table 1: Relative LC peak areas in the chromatograms of the irradiated MLT sample solutions.

\begin{tabular}{|c|c|c|c|c|c|c|}
\hline \multirow{2}{*}{ No. } & \multirow{2}{*}{$\begin{array}{l}\text { Irradiation dose } \\
\qquad(\mathrm{Gy})\end{array}$} & \multicolumn{4}{|c|}{$\begin{array}{l}\text { Relative peak area at specified retention } \\
\text { time }\end{array}$} & \multirow{2}{*}{$\begin{array}{l}\text { total peak } \\
\text { areas }\end{array}$} \\
\hline & & $\begin{array}{c}\text { I, } \\
11.6 \mathrm{~min}\end{array}$ & $\begin{array}{l}\text { II, } \\
12.0 \mathrm{~min}\end{array}$ & $\begin{array}{c}\text { III, } \\
12.8 \mathrm{~min}\end{array}$ & $\begin{array}{c}\text { MLT } \\
13.3 \mathrm{~min}\end{array}$ & \\
\hline $1^{\mathrm{a}}$ & 0 & 0.0 & 0.0 & 0.0 & 100 & 100 \\
\hline 2 & 20 & 0.0 & 0.0 & 0.0 & 100 & 100 \\
\hline 3 & 50 & 0.0 & 0.0 & 0.0 & 100 & 100 \\
\hline 4 & 120 & 0.0 & 0.2 & 0.3 & 99.4 & 99.9 \\
\hline 5 & 500 & 0.0 & 1.5 & 1.2 & 97.3 & 100 \\
\hline 6 & 2150 & 1.6 & 1.6 & 0.9 & 95.1 & 99.2 \\
\hline
\end{tabular}

revealed that the molecular weight of this compound is only 2unit more than MLT. Based on this fact, it was concluded that in compound I, one of the double bonds on MLT has converted into a single bond.

The compound whose ESI-MS spectrum provides enough evidence for the formation of oxidized form of MLT is the compound II. The mass spectrum of this compound and the results of the interpretation of this spectrum are provided (Figure 5). Compound II has an ESI-MS spectrum (Figure 5) in which most intense ions have found at 16units higher $\mathrm{m} / \mathrm{z}$ than the ions in the ESI-MS spectrum of MLT (Figure 2). Such data provide reasonable indication for the existence of the oxidized species of MLT in the solution. It is noteworthy that observation of adduct ions such as $\mathrm{M}+\mathrm{H}$ [M: MLT molecule], $\mathrm{M}+\mathrm{Na}, \mathrm{M}+\mathrm{K}$, and dimer ions in LC-MS are usual [11], and those data together provide enough information to assign molecular weight for the interested molecule. Based on ESIMS data, it is not possible to definitely assign the attachment point of oxygen atom on MLT; but BonnefontRousselot, et al., stated that benzene like ring in MLT molecule is more ready for oxidation than the other parts of it [12]. Although it seems due to $\pi$-excessive ring, pyrrole ring in $\mathrm{MLT}$ is more attractive for $\mathrm{OH}$; another mechanism for MLT oxidation by $\mathrm{OH}$, has been proposed by Allegra, et al., in which another part of MLT is affected and a three cyclic compound is formed [13].

Mark-Trojanowicz, et al., pointed out that due to water molecule radiolysis, the following species are formed, at the radiation point of action with corresponding radiationchemical yield (G-value) which is expressed in $\mu \mathrm{mol} / \mathrm{J}$ [14].

$\mathrm{H}_{2} \mathrm{O}-\ldots \rightarrow \mathrm{OH}(0.28), e_{a q}^{-}(0.28), H(0.062), \mathrm{H}_{2}(0.047), \mathrm{H}_{2} \mathrm{O}_{2}(0.073)$,
$\mathrm{H}_{3} \mathrm{O}^{+}(0.28)$

Upon formation, these and other secondary species are rapidly and homogeneously dispersed in the solution and may interact with other molecules, radical and ionic species, and are finally eliminated. The primary basic radicals, namely $\cdot H$ and $\cdot \mathrm{OH}$, quickly enter into acid-base equilibriums:

$$
\begin{aligned}
& \mathrm{H} .+\mathrm{HO}-\longrightarrow \text { eaq }-+\mathrm{H}_{2} \mathrm{O} \\
& \mathrm{OH}+\mathrm{HO}^{-} \leftarrow \rightarrow \mathrm{O}^{--}+\mathrm{H}_{2} \mathrm{O}
\end{aligned}
$$

Hydrogen radical $(\cdot \mathrm{H})$ and hydrated electron $\left(\mathrm{e}^{-}{ }_{\mathrm{aq}}\right)$ are in the acid-base equilibrium with $\mathrm{pK}_{\mathrm{a}}=9.1$. In highly alkaline environments, $\cdot \mathrm{H}$ atoms are converted to $\mathrm{e}^{-}$aq with the rate constant of $2.2 \times 10^{7} \mathrm{M}^{-1} \mathrm{Sec}^{-1}$. Since the process of electron or ${ }^{\cdot} \mathrm{H}$ atom donation in water is slow, the lifetime of $\mathrm{e}^{-}$aq is relatively high [14].

Also, hydroxyl radical $(\cdot \mathrm{OH})$ is in an acid-base equilibrium with $\mathrm{pK}_{\mathrm{a}}=11.8$ with the $\mathrm{O}^{-}$- species. The rate constant of forward equilibrium reaction from hydroxyl to radical oxygen was reported to be $1.3 \times 10^{10} \mathrm{M}^{-1} \mathrm{sec}^{-1}$; and the rate constant for the reverse reaction equals to $7.9 \times 10^{7} \mathrm{M}^{-1} \mathrm{sec}^{-1}$ [14].

Simultaneous presence of reduced (I) and oxidized (II) forms of MLT as reaction products in the irradiated solution is an interesting point. With respect to the data shown in Table 1, concentration of those species in the solution are close together. This can be related to radical dissociation of water molecules due to irradiation. It has been showed that the oxidation/reduction properties of radicals resulting from the radiolysis of water are due to the following: a) The impact of $\mathrm{OH}$ radical, which is a strong oxidant, and its oxidation potential varies due to solution $\mathrm{pH}$ from $11.9 \mathrm{~V}$ for $\cdot \mathrm{OH} /{ }^{-} \mathrm{OH}$ to 12.72 $\mathrm{V}$ for $\mathrm{OH}, \mathrm{H}^{+} / \mathrm{H}_{2} \mathrm{O}$ and; b) hydrated electron $\left(\mathrm{e}^{-}{ }_{\mathrm{aq}}\right)$ which is a powerful reducing agent in neutral and alkaline solutions with reduction potential of $22.87 \mathrm{~V}$ [14]. In acidic media, ${ }^{\circ} \mathrm{H}$ is the major reducing agent with reduction potential of $22.31 \mathrm{~V}$. Such 


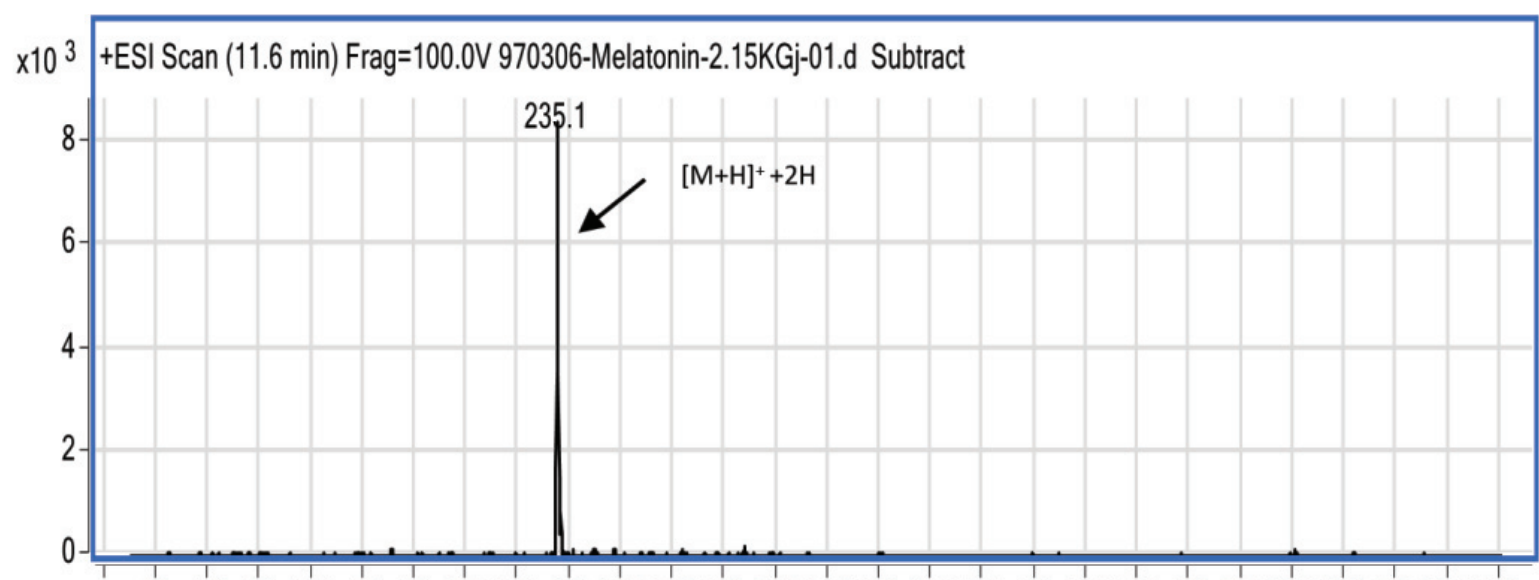

80100120140160180200220240260280300320340360380400420440460480500520540560580600

Counts vs. Mass-to-Charge ( $\mathrm{m} / \mathrm{z})$

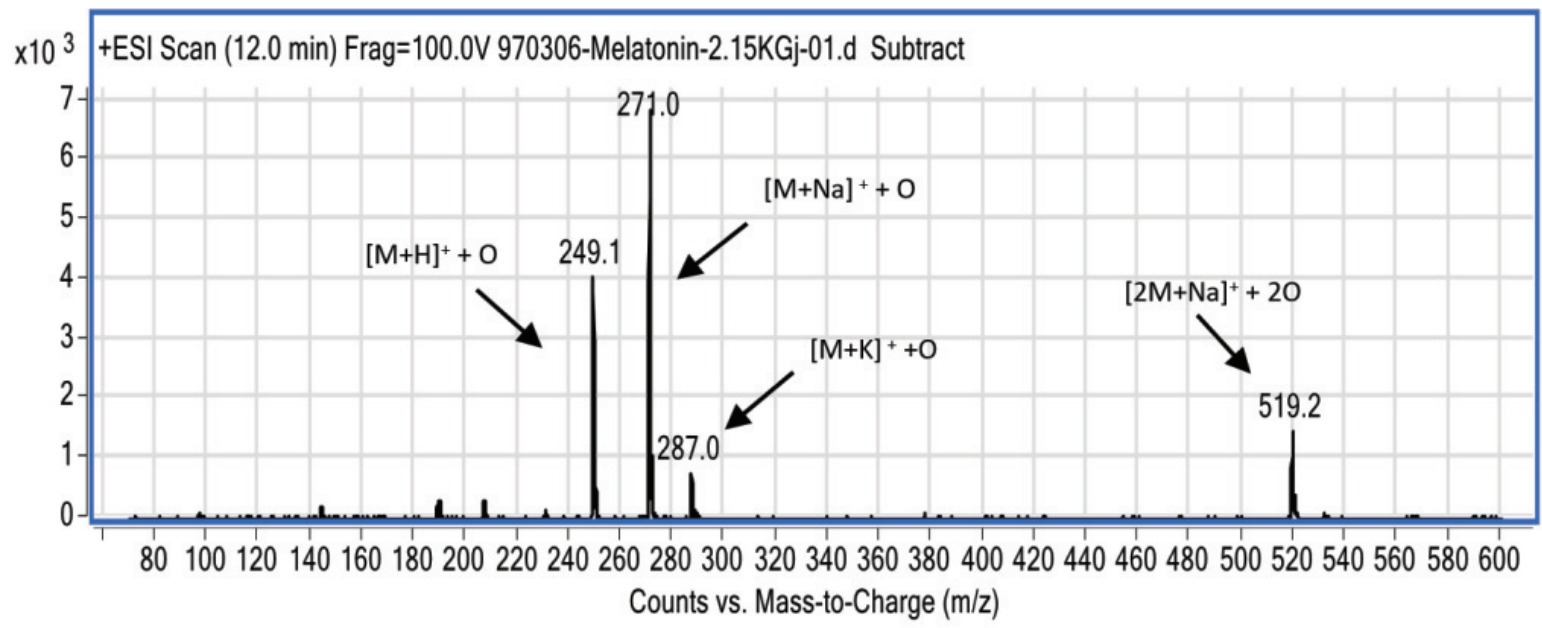

Figure 5: ESI-MS spectrum of compound II (retention time: 12.0min); as a product of the irradiation of MLT solution by gamma rays at dose of 2150Gy.

active species react with other molecules in water solution; and as an interesting finding, unlike other oxidizing or reducing processes, irradiation of water solution of a chemical might produce both the chemical's oxidation and reduction products $[14,15]$.

According to data collected from the ESI-MS spectrum of compound III (Figure 6), its molecular weight equals to 276amu. The ions with the $\mathrm{m} / z 299$ and 575 correspond to $\mathrm{M}^{\prime}+\mathrm{Na}$ and $2 \mathrm{M}^{\prime}+\mathrm{Na}$, respectively. The ion which can be seen at $\mathrm{m} / \mathrm{z} 259$ is related to an ionic species which is obtained from the removal of a water molecule and addition of a proton to it, i.e. $M^{\prime}+H$. The ion with $m / z 315$ seems to be potassium adduct of the molecule, $M^{\prime}+K$. The molecular weight difference between this new species ( $M^{\prime}$ ) and MLT is 44amu. Firstly, it should be noted that this compound has a hydroxyl group, due to the elimination of water in one of the ESI fragmentation process and formation of an ion with $\mathrm{m} / \mathrm{z} 259$. There is no such a group on MLT. So it might be a) a reaction product of reduced MLT, which may have a hydroxyl group, and or b) a consecutive oxidation product of MLT which have an acidic group which under ESI, loses a $\mathrm{CO}_{2}$ group. In analysis of these two possibilities it should be noted that the only reasonable position for reduction of MLT and formation of an alcoholic group, is the amidic $\mathrm{C}=\mathrm{O}$ bond. Due to the presence of the ion which is seen at $\mathrm{m} / \mathrm{z} 200$, with 5 amu difference between $\mathrm{m} / \mathrm{z}$ of this ion and the ion at $\mathrm{m} / z 259$ (Figure 6) and considering the ESI mass spectrum of MLT (Figure 2), it is found out that the amide group on compound III has remained intact. It seems that the ion which appeared at $\mathrm{m} / \mathrm{z} 200$ is formed after elimination of amide group from the structure of the ion at $m / z$ 259. So the first possibility is rejected, or can be considered as the less effective process. To examine the second possibility, it must be kept in mind that $\mathrm{CO}_{2}$ origin should be in the gamma rays radiated aqueous solution of MLT. Since similar peak could not be seen in MLT control sample chromatogram (Figure 1), formation of compound III could not be attributed to the formic acid which is present in LC eluent composition. BonnefontRousselot, et al., proposed a mechanism for oxidation of MLT in which formic acid is released [12]. According to Hart [18] formic acid in water solution under gamma radiation may produce active formyloxyl radical, HCOO: 


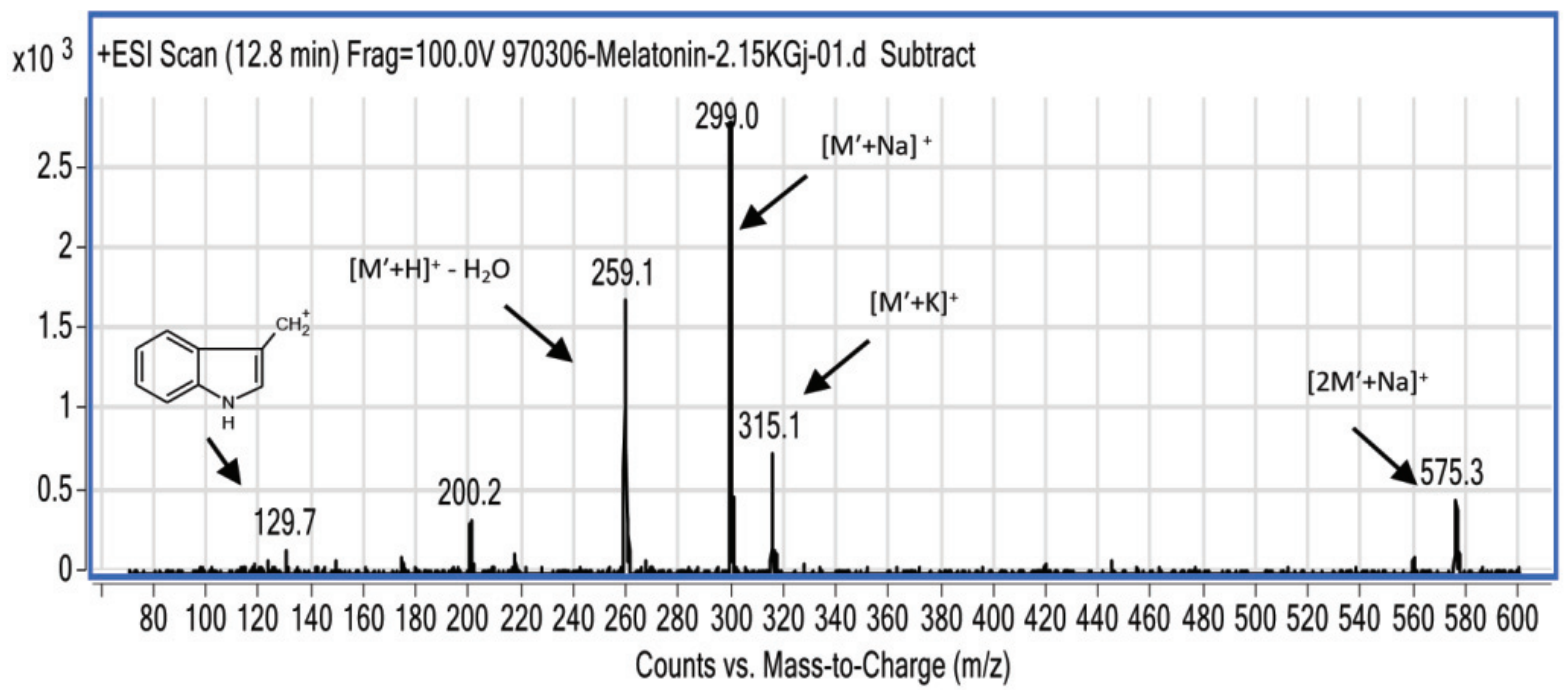

Figure 6: ESI-MS spectrum of compound III (retention time: $12.8 \mathrm{~min}$ ); at a product of the irradiation of MLT solution by gamma rays at dose of $2150 \mathrm{~Gy}$.

$\mathrm{H}+\mathrm{HCOOH}^{\rightarrow} \leftarrow \rightarrow \mathrm{H}_{2}+\mathrm{HCOO}$

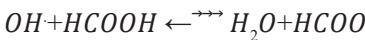

This radical, likely attacks to MLT to produce compound III with molecular weight of 276.

$\mathrm{HCOO}+(\mathrm{MLT}-\mathrm{H}) \rightarrow(\mathrm{MLT}-\mathrm{OOC})+\mathrm{H}$

Note that in this reaction pathway, (MLT-H) and (MLT$\mathrm{OOC}$ ) are arbitrary symbols in order to represent single $\mathrm{H}$ atom and $\mathrm{CO}_{2}$ bonded to MLT.

\section{Powder samples analyses}

LC-MS analyses showed no any significant difference between the control sample chromatogram and chromatograms obtained from analysis of irradiated dry powder samples. This inactivity are attributed to the low cross section of MLT for gamma radiation.

The cross section is a convenient quantity to discuss the interactions of particles in matter [16]. In solution samples in which MLT molecules are dispersed in water, number of water molecules are much more than MLT molecules, and as a consequence, probability of the interaction of photons with atoms on water molecules is more than of MLT [16]. After aqueous solutions irradiation, and water radically dissociation, radical reactions are started. But in solid samples, despite the larger molecular dimension of MLT compared with water, the interaction between photons and atoms on MLT molecules are weaker than in solution. Mahfouz, et al., reported a similar observation and a significant difference in the amount of irradiation products of solid iodophenol and its watermethanol solutions [17]. They reported in their study that the formation of products derived from radiolysis is mainly due to the formation of $\cdot \mathrm{H}, \cdot \mathrm{OH}$ and $\mathrm{e}^{-}{ }_{\text {aq }}$. In fact, when photons collide to MLT atoms, an active species would not be obtained for the subsequent chemical reaction. Even, if reactive species are formed, reaction in a solid matrix may not proceed, due to lower space for motion and collision. In this study, analyses of solid MLT samples after irradiation revealed no any degradation product.

\section{Conclusion}

Based on findings of this research, it was concluded that A) with an increased dose of gamma radiation on MLT solutions, MLT structure are changed. After irradiation, MLT concentration is reduced and new compounds are formed and their concentrations gradually increased, in accordance with the received dose. B) MLT structural changes were seen in solutions which are irradiated by gamma rays with dose of 50Gy and greater. C) In this study, three different chemicals, reduced (I), oxidized (II), and $\mathrm{CO}_{2}$ adduct (III) forms of MLT were identified, using LCMS. All product compounds were found in aqueous MLT solutions. D) After gamma rays exposure, chemical structure of dry powder MLT was not changed. It was mentioned that this finding is due to the lower cross section of MLT, as compared with water in aqueous samples.

\section{References}

1. Foye WO (1998) History of Radioprotector Development. Radioprotectors: Chemical, Biological, and Clinical Perspectives. In Radioprotectors, Chemical, Biological and Clinical Perspectives, Bump EA and Malaker K (Eds.) CRC Press 15-24.

2. Hosseinimahr SJ (2007) Natural products with radiation protection Mazandaran J Med Sci 17: 189-175. Link: http://bit.ly/388nOcL

3. Hosseinimehr SJ (2007) Trends in the development of radioprotective agents. Drug Discov Today 12: 794-805. Link: http://bit.ly/39gVXaM

4. Citrin D, Cotrim AP, Hyodo F, Baum BJ, Krishna MC, et al. (2010) Radioprotectors and mitigators of radiation-induced normal tissue injury. Oncologist 15: 360371. Link: http://bit.ly/377u2Zl

5. Vijayalaxmi, Reiter RJ, Tan DX, Herman TS, Thomas CR (2004) Melatonin as a radioprotective agent: a review. Int J Radiat Oncol Biol Phys 59: 639-653. Link: http://bit.ly/39gYnWQ

6. Leston J, Harthe C, Brun J, Mottolese C, Mertens P, et al. (2010) Melatonin 
is released in the third ventricle in humans. A study in movement disorders. Neurosci lett 469: 294-297. Link: http://bit.ly/2S9EJq5

7. Vijayalaxmi, Meltz ML, Reiter RJ, Herman TS, Kumar S (1999) Melatonin and protection from whole-body irradiation: survival studies in mice. Mutation Res 425: 21-27. Link: http://bit.ly/378IBwC

8. Cui P, Luo Z, Zhang H, Su Y, Li A, et al. (2006) Effect and mechanism of melatonin's action on the proliferation of human umbilical vein endothelial cell. J Pineal Res 41: 358-362. Link: http://bit.ly/3bjRbLm

9. Jang SS, Kim WD, Park WY (2009) Melatonin exerts differential actions on $\mathrm{X}$-ray radiation-induced apoptosis in normal mice splenocytes and Jurkat leukemia cells. J Pineal Res 47: 147-155. Link: http://bit.ly/2UEe1qW

10. Lissoni P, Rovelli F, Malugani F, Bucovec R, Conti A, et al. (2001) Anti-angiogenic activity of melatonin in advanced cancer patients. Neuro Endocrinol Lett 22 45-48. Link: http://bit.ly/2UwMw2E

11. Almeida EA, Klitzke CF, Martinez GR, Medeiros MH, Mascio PD (2004) Synthesis of internal labeled standards of melatonin and its metabolite N1acetyl-N2-formyl-5-methoxykynuramine for their quantification using an online liquid chromatography-electrospray tandem mass spectrometry system. J Pineal Res 36: 64-71. Link: http://bit.ly/378n2ew

12. Bonnefont-Rousselot D, Collin F, Jore D, Gardès-Albert M (2011) Reaction mechanism of melatonin oxidation by reactive oxygen species in vitro. $J$ Pineal Res 50: 328-335. Link: http://bit.ly/2uuxQq2

13. Allegra M, Reiter RJ, Tan DX, Gentile C, Tesoriere L, et al. (2003) The chemistry of melatonin's interaction with reactive species. J Pineal Res 34: 1-10. Link: http://bit.ly/2SoUyrQ

14. Trojanowicz M, Bobrowski K, Szreder T, Bojanowska-Czajka A (2018) Gammaray, X-ray and Electron Beam Based Processes. In Advanced Oxidation Processes for Waste Water Treatment. Academic Press 257-331. Link: http://bit.ly/2UxczqA

15. Allen AO (1952) Mechanism of decomposition of water by ionizing radiations. Discussions of the Faraday Society 12: 79-87. Link: https://rsc.li/2UyKOOc

16. Tavernier $S$ (2010) Experimental techniques in nuclear and particle physics Springer-Verlag Berlin Heidelberg 23-45. Link: http://bit.ly/3769P67

17. Mahfouz RM, Siddiqui MR, Al-Wassil Al, Al-Resayes SI, Al-Otaibi AM (2005) Chemical effects induced by $\mathrm{Y}$-irradiation in solid and in aqueous methanol solutions of 4-iodophenol. Radiation Effects and Defects in Solids 160: 173180. Link: http://bit.ly/3bm2hiK

18. Hart EJ (1954) Gamma-Ray Induced Oxidation of Aqueous Formic Acid Oxygen Solutions. Effect of Oxygen and Formic Acid Concentrations. J Am Chem Soc 76: 4312-4315. Link: http://bit.ly/2St1CDx
Discover a bigger Impact and Visibility of your article publication with

\section{Peertechz Publications}

Highlights

* Signatory publisher of ORCID

* Signatory Publisher of DORA (San Francisco Declaration on Research Assessment)

- Articles archived in worlds' renowned service providers such as Portico, CNKI, AGRIS, TDNet, Base (Bielefeld University Library), CrossRef, Scilit, J-Gate etc.

* Journals indexed in ICMJE, SHERPA/ROMEO, Google Scholar etc.

* OAl-PMH (Open Archives Initiative Protocol for Metadata Harvesting)

* Dedicated Editorial Board for every journal

* Accurate and rapid peer-review process

* Increased citations of published articles through promotions

* Reduced timeline for article publication

Submit your articles and experience a new surge in publication services (https://www.peertechz.com/submission).

Peertechz journals wishes everlasting success in your every endeavours.

Copyright: @ 2020 Safdari AR, et al. This is an open-access article distributed under the terms of the Creative Commons Attribution License, which permits unrestricted use distribution, and reproduction in any medium, provided the original author and source are credited.

Citation: Safdari AR, Babri M (2020) Liquid Chromatography-Mass Spectrometry studies on molecular structure of melatonin after Co-60 gamma irradiation. Open Journal of Chemistry 6(1): 001-007. DOI: https://dx.doi.org/10.17352/ojc.000015 